УДК 784.3.071.1 : 82-1 (477), DOI 10.34064/khnum1-5007

ORCID 0000-0003-3510-3213

\title{
Ван Дуангуй
}

Харківський національний університет мистецттв імені

I. П. Котляревського

\section{ПЕРЕСЕМАНТИЗАЦІЯ ПОЕЗІЇ О. ПУШКІНА В ТВОРЧОСТІ В. КОСЕНКА (НА ПРИКЛАДІ «П'ЯТИ РОМАНСІВ» ор. 20)}

\section{АНОТАЦІЯ}

Ван Дуангуй. Пересемантизація поезії О. Пушкіна в творчості В. Косенка (на прикладі «П'яти романсів» ор. 20). У статті пропонується досвід стильового аналізу одного з кращих зразків української вокальної лірики першої третини ХХ ст. Твір 1930 року характеризує зрілий стиль композитора, що сформувався, $з$ одного боку, під впливами європейського романтичного мистецтва. 3 іншого боку - сутність українського жанру «солоспів» розкриває опукла національна пісенно-романсова інтонація, сповнена не лише романтичного світоспоглядання, але й якоїсь особистої, щирої, інтимно-цнотливої лірики. Парадокс полягає в тому, що, хоча поезія Пушкіна утілена у «цілісній адекватності» (за А. Хуторською), і композитор знайшов максимально повний смисловий аналог поетичного першоджерела, однак при цьому музична семантика новотвору не є відповідною усталеним уявленням про стилістику російської пісні-романсу. Робиться висновок: солоспіви належать до типу вільного художнього перекладу з узагальнено-жанровою адекватністю. Відбувається пересемантизація першоджерела за рахунок іншостильових складників музичного втілення поетичних образів. Мелос, ритміка, елементи фактурного викладу (втори, стилізація різних жанрових формул) свідчать про красу вокального стилю В. Косенка, духовну зрілість майстра української вокальної культури, яка, входячи у «слов'янський пісенний ареал», разом з тим ментально відрізняється від російської та загальноєвропейської стильової системи (картини світу).

Ключові слова: солоспів (романс), міжвидовий художній переклад, пересемантизація, романтичний стиль, українська національна інтонація.

\section{АННОТАЦИЯ}

Ван Дуангуй. Пересемантизация поэзии А. Пушкина в творчестве В. Косенко (на примере «Пяти романсов» ор. 20). В статье предложен опыт стилевого анализа одного из лучших образцов украинской вокальной лирики первой трети XX в. Сочинение 1930 года характеризует зрелый стиль композитора, который сформировался, с одной стороны, под влиянием европейского романтизма. С другой - сущность украинского жанра «солоспів» раскрывает выпу- 
клая национальная песенно-романсовая интонация, напоённая не только романтическим мировосприятием, но какой-то личной искренностью, интимной, целомудренной лирикой. Парадокс заключается в том, что, хотя поэзия Пушкина и воплощена в «целостной адекватности» (А. Хуторская), и композитором найден максимально полный смысловой аналог поэтического первоисточника, однако при этом музыкальная семантика нового сочинения не соответствует устоявшимся представлениям о стилистике русского романса. Сделан вывод: «солоспивы» В. Косенко принадлежат к типу свободного художественного перевода с обобщённо-жанровой адекватностью. Происходит пересемантизация первоисточника за счёт иностилевых факторов музыкального воплощения поэтических образов. Мелос, ритмика, фактурное изложение (вторы, стилизация разных жанровых формул) свидетельствуют о редкой красоте вокального стиля Косенко, духовной силе и зрелости мастера украинской вокальной культуры, которая, входя в «славянский песенный ареал», вместе с тем ментально отличается от общеевропейской стилевой системы (картины мира).

Ключевые слова: солоспив (романс), межвидовой художественный перевод, пересемантизация, романтический стиль, украинская национальная интонация.

ABSTRACT

Wang Duangui. Re-semantization of A. Pushkin's poetry in the creative work of V. Kosenko (on the example of "The Five Romances", op. 20).

Formulation of the problem. In the chamber-vocal genre, the composer exists in two images: he is both the interpreter of the poetic composition and the author of a new synthetic music and poetic composition. The experience of the style analysis of one of the best examples of Ukrainian vocal lyrics of the first third of the 20th century shows that the cycle op. 20 characterizes the mature style of the composer, which was formed, on the one hand, under the influence of European Romanticism. On the other hand, the essence of the Ukrainian "branch" of the Western European song-romance ("solo-singing") is revealed by the prominent national song-romance intonation, filled with not only a romantic worldview, but also with some personal sincerity, chastity, intimate involvement with the great in depth and simplicity poetry line, read from the individual position of the musician. The paradox is as follows. Although Pushkin's poetry is embodied in a "holistic adequacy" (A. Khutorska), and the composer found the fullest semantic analogue of the poetic source, however, in terms of translating the text into the Ukrainian language, the musical semantics changes its intonation immanence, which naturally leads to inconsistency of the listeners' position and ideas about the style of Russian romance. We are dealing with inter-specific literary translation: Pushkin's discourse creates the Ukrainian romance style and system of figurative thinking.

The purpose of the article is to reveal the principle of re-semantization of the intonation-figurative concept of the vocal composition by V. Kosenko (in the context of translating Pushkin's poetry into the Ukrainian language) in light of the theory of interspecific art translation. 
Analysis of recent publications on the topic. Among the most recent studies of Ukrainian musicology, one should point out the dissertation by G. Khafizova (Kyiv, 2017), in which the theory of modelling of the stylistic system of the vocal composition as an expression of Pushkin's discourse is described. The basis for the further stylistic analysis of V. Kosenko's compositions is the points from A. Khutorska's candidate's thesis; she develops the theory of interspecific art translation. The types of translation of poetry into music are classified according to two parameters. The exact translation creates integral adequacy, which involves the composer's finding a maximally full semantic analogue of the poetic source. The free translation is characterized by compensatory, fragmentary, generalized-genre adequacy.

Presenting the main material. The Zhitomir period for Viktor Kosenko was the time of the formation of his creative style. Alongside the lyrical imagery line, the composer acquired one more - dramatic, after his mother's death. It is possible that the romances on the poems of A. Pushkin are more late reflection of this tragic experience (op. 20 was created in 1930).

"I Loved You" opens the vocal cycle and has been dedicated by A. V. Kosenko. The short piano introduction contains the intonation emblem of the love-feeling wave. The form of the composition is a two-part reprising $\left(A A_{l}\right)$ with the piano Introduction and Postlude. The semantic culmination is emphasized by the change of metro-rhythmic organization 5/4 (instead of 4) and the plastic phrase "as I wish, that the other will love you" sounding in the text. Due to these melodies (with national segments in melo-types, rhythm formulas and harmony) V. Kosenko should be considered as "Ukrainian Glinka", the composer who introduced new forms and "figures" of the love language into the romantic "intonation dictionary". In general, V. Kosenko's solo-singing represents the Ukrainian analogue of Pushkin's discourse - the theme of love. The melos of vocal piece "I Lived through My Desires" is remembered by the broad breath, bright expression of the syntactic deployment of emotion. On the background of bass ostinato, the song intonation acquires a noble courage. This solo-singing most intermediately appeal to the typical examples of the urban romance of Russian culture of the 19th century.

"The Raven to the Raven" - a Scottish folk ballad in the translation by A. Pushkin. V. Kosenko as a profound psychologist, delicately transmits the techniques of versification, following each movement of a poetic phrase, builds stages of the musical drama by purely intonation means. The semantics of a death is embodied through the sound imaging of a black bird: a marching-like tempo and rhythm of the accompaniment, with a characteristic dotted pattern in a descending motion (like a raven is beating its wings). The middle section is dominated by a slow-motion perception of time space (Andante), meditative "freeze" (size 6/4). The melody contrasts with the previous section, its profile is built on the principle of descending move: from " $\mathrm{h}$ " " to " $\mathrm{h}$ " of the small octave (with a stop on S-harmony), which creates a psychologically immersed state, filled by premonition of an unexpected tragedy. In general, the Ukrainian melodic intonation intensified the tragic content of the ballad by Pushkin. The musical semantics of V. Kosenko's romances is marked by the dependence on the romantic "musical vocabulary", however, it is possible to indicate and na- 
tional characteristics (ascending little-sixth and fifth intervals, which is filled with a gradual anti-movement; syllabic tonic versification, and other).

Conclusion. The romances ("solo-singings") by V. Kosenko belongs to the type of a free art translation with generalized-genre adequacy. There is a re-semantization of poetic images due to the national-mental intonation. Melos, rhythm, textural presentation (repetitions), stylization of different genre formulas testify to the rare beauty of Kosenko's vocal style, spiritual strength and maturity of the master of Ukrainian vocal culture. Entering the "Slavic song area", the style of Ukrainian romance, however, is differenced from the Russian and common European style system of figurative and intonation thinking (the picture of the world).

Key words: solo-singing (romance), inter-specific literary translation, re-semantization, romantic style, Ukrainian national intonation.

Постановка проблеми. У камерно-вокальному жанрі композитор постає у двох іпостасях: він $є$ і інтерпретатором поетичного твору i, водночас, автором нового синтетичного музично-поетичного твору. Вірші російського письменника і поета Олександра Пушкіна стали основою для багатьох романсів композиторів різних часів. Ще сучасники Олександра Сергійовича, захоплюючись красою його поезії, створювали романси на його вірші. Серед відомих - романси О. Верстовського «Сльххали ль вы за рощуей глас ночной», «Старый муж, грозный муж»), «Поэт»). «Пушкін відкрив для російської поезії пісенність», ця думка, висловлена в одному з виступів музикознавцем і композитором Ф. Софроновим, може пояснити таку велику кількість звернень композиторів, що є представниками різних епох, стилів та напрямків до його творчості (що триває вже понад двісті років!). На його вірші створювали романси О. Алябьєв, М. Глінка, П. Чайковський, С. Рахманінов, Г. Свиридов. Не оминули поезію Пушкіна і українські композитори. Серед класики першої третини ХХ ст. - вокальні твори Віктора Степановича Косенка, які сьогодні оцінюють як «діамантовий вінок» українському солоспіву.

Аналіз останніх публікацій за темою. Серед новітніх досліджень українського музикознавства слід вказати на статтю О. Тюріної [1] та дисертацію Г. Хафізової (Київ, 2017), у якій викладено досвід теоретичного моделювання стильової системи вокального твору як увиразнення пушкінського дискурсу [2]. Підгрунтям для подальшого стильового аналізу творів В. Косенка слугують положення з дисертації А. Хуторської [3]. Типи перекладу класифікуються за двома параметрами. 
Точний переклад характеризують: а) цілісна адекватність, яка передбачає знаходження композитором максимально повного смислового аналога поетичного першоджерела; б) образно-емоційна адекватність - втілення змісту першоджерела з незначними змінами у структурі оповідання (повтор слів тощо). Відмінності висхідних та інтерпретуючих знаків пояснюються мовною несумірністю оригіналу та перекладу, або специфікою історико-культурних традицій. Вільний переклад характеризують: а) компенсаторна адекватність, коли деякі елементи поетичного першоджерела, які композитор не в змозі передати, компенсуються новою музичною образністю; б) фрагментарна адекватність (часткове використання поетичних джерел); в) узагальненожанрова адекватність - збереження жанрово-стильових параметрів поетичного першоджерела, але семантична складова передається в узагальненому виді.

Мета статті - розкрити механізм пересемантизації інтонаційнообразної концепції вокального твору В. Косенка на поезію О. Пушкіна українською мовою в світлі теорії міжвидового художнього перекладу.

Матеріалом слугують солоспіви: «Я вас кохав» № 1, «Я пережив свої бажання» № 2, «Крук до круку» № 3, «Вечірня пісня» № 4, «Старовинна пісня» № 5 .

Виклад основного матеріалу. Житомирський період для Вiктора Косенка був часом його становлення як митця, формування його творчого стилю. Композитор активно працював у камерноінструментальному та вокальному жанрах. Романси, створені упродовж 1919-1924 pр., передають ліричні почуття, любов до дружини. Їй присвячені майже всі твори тих років: мазурки, ноктюрни, менует, колискові, солоспіви.

Через усе життя проніс Віктор Степанович почуття світлої любові до своєї матері. Коли вона померла, у творчості композитора, поряд 3 ліричною лінією образності, з'явилась драматична. Під впливом великого горя, яке спіткало його, був написаний романс «Смерть матері» (1919) на слова П.-Ж. Беранже. Не виключено, що «Романси на вірші О. Пушкіна» віддзеркалюють рефлексії пережитого горя, закарбовані у більш зрілому віці (опус створений у 1930 р.). На думку I. Варвенчука, «звернення до текстів російських поетів резонувало з інтимносуб'єктивними, іноді меланхолійними настроями, мрійливістю, спогляданням, почуттям смутку, що часто навідували В. Косенка в так зва- 
ний житомирський період» ${ }^{1}$. В інтерпретації В. Косенка тексти романсів подані у перекладі на українську мову².

Перейдемо до аналізу інтонаційної драматургії циклу ор. 20 В. Косенка. Відкриває твір солоспів «Я Вас кохав» із присвятою А. В. Косенко. Короткий вступ фортепіано містить емблематику любовно-чуттєвої хвилі: романтичні «зітхання» звучать в ладо-гармонічній «окрасі» альтерацій та хроматизмів у акордах із великими септакордами та прохідними звуками і перебігами.

Композиція солоспіву - репризна двочастинна (А $\left.\mathrm{A}_{1}\right)$ із фортепіанним вступом (2 такти) та вагомою постлюдією (на інтонаціях основної теми). У вокальній партії переважає кантиленна мелодія широкого дихання, гармонізована секвенціями (на кшталт лейтмотиву Тетяни, яким розпочинається опера П. Чайковського «Євгеній Онєгін»). Характерний зачин теми-мелодії $(4+4)$ розпочинається не в умовах тоніки, а в зоні оспівування субдомінантового тону «а». В мелодію плавного руху органічно «вбудовані» стрибки на велику сексту (на слова «кохання пал») та чисту квінту («не тривоже») вниз, які мають підкреслити семантику того чи іншого слова.

У другому реченні звучить висхідний стрибок на малу сексту (на слова «не хочу Вас) з подальшим оспівуванням терції («нічим журити») несподіваного B-dur (мажоро-мінорне зіставлення). 3 точки зору тонального плану експозиція $є$ розімкненою, як ознака «відкритого» серця, щирого чуття, що заповнює все навкруги себе. Фортепіанний звукообраз насичений постійним рухом шістнадцятих, що доповнює пісенну інтонацію внутрішньою пульсацією та відчуттям щільності кожної миті.

Другий розділ $\left(\mathrm{A}_{1}\right)$ розпочинається варіантом основної темимелодії на терцію вище, переходячи в основну тональність у серединному кадансі на домінантовій гармоній. Четверте речення $є$ кульмінаційним, про що свідчить найвищий регістр басового голосу $\left(\mathrm{g}^{2}, \mathrm{fis}^{2}\right)$,

1 Вавренчук I. Сецесійні акценти у вокальній ліриці В. Косенка. URL : Se\%D1\%81es\%D1\%96jjn\%D1\%96_ak\%D1\%81enti_u_vokal/1.html (дата звернення: 15.07 .2018$)$.

2 Перекладом солоспівів «Я Вас кохав» $\mathrm{i}$ «Вечірня пісня» займався М. Чернявський (1868-1938), а інших - М. Рильський («Я пережив своїх бажання»). Багато віршів російських письменників, що слугували поетичною основою солоспівів В. Косенка, переклав Л. Первомайський (для прикладу наведемо романс «Мені сумно» на вірші М. Лермонтова). 
гучна динаміка та незвична зупинка хроматизованого сходження на тлі альтерованих субдомінант в акордовому супроводі фортепіано. Смислова кульмінація підкреслена зміною метроритмічної організації (5/4 замість усталеного 4-дольника) та фактурним викладом - рамплісажні арпеджіо охоплюють весь регістровий діапазон фортепіанного супроводу, на тлі якого вимальовується пластика чуття смиренної любові: «як зичу Вам, щэоб інший Вас кохав».

Знаменною ознакою $є$ завершення вокальної мелодії любовного признання на кульмінаційному тоні, в зоні тональної нестійкості (хоча VI щабель входить у структуру домінантового нонакорду в кадансі фортепіанної партіі). Пластика завершальної хвилеподібної фрази полягає також в наявності ритмічного малюнку вісімками, в який «вкраплено» висхідну інтонацію романсу (ввідний тон до субдомінанти). Усередині цієї мелодії є стрибок на тритон (вперше!) як ознака болісного чуття, а подальше сходження до тоніки через стрибок вниз на слабкій долі з поверненням до медіанти VI щаблю - зупиняє вокальну партію, робить ії знов «відкритою», немов зупинка серця (крапки просто не може бути!). Саме за такі мелодії (з національними мелотипами, ритмами, ладо-гармоніями) В. Косенка вважають українським Глинкою, композитором, який вніс в романтичний «інтонаційний словник» вокальної музики національні образи та «фігури» любовної мови. В иілому тема кохання у солоспіві В. Косенка являє собою украйнський аналог пушкінського дискурсу в інтонаційно-жанровій та індивідуально-стильовій формі.

«Я пережив свої бажання» - типовий зразок любовної лірики на інтонемах побутового романсу, що в російській культурі XIX ст. набув значення іiі «візитівки». У загальному плані стилістика цього солоспіву апелює до відомої елегії О. Бородина «Для берегов отчизни дальной». Тональність es-moll від початку надає музиці трагедійного звучання. Серед типових інтонем, що впізнаються як елегійна лірика фрігійський мінор (другий знижений щабель), висхідна мала секста на початку теми та в їі кульмінації'; зменшена кварта вверх (у кадансі, тт. 8-9) - знак «згорнутої всередину себе» душевної туги; ходи по зву-

1 Ї̈̈ можна вважати «жанровим генокодом», що перейшов від народної протяжної ліричної пісні до класичної пісні-романсу М. Глінки, П. Чайковського, а потім вже - в неоромантизм XX століття. 
ках мінорного квартсекстакорду, малого з мінором; у кадансових зонах - стрибки вниз на октаву та малу септиму, а також зворот «VII підвищена $-\mathrm{V}$ вверх - T».

Солоспів відрізняється складною насиченою фактурою фортепіанного супроводу, що свідчить про можливості автора як чудово обізнаного піаніста, який розуміється на своєму інструменті та використовує його потенціал як поет (на кшталт Ф. Шуберта чи Р. Шумана, німецьких романтиків-ліриків - творців психологічної вокальної мініатюри). Розшарування фортепіанної фактури на три пласти надає музиці емоційно-психологічного напруження, віртуозного блиску, просторовості сприйняття: 1) остинатний бас - «передчуття смертного часу» (на Т-органному пункті з синкопою на сильній долі); 2) акордові педалі та акорди-грона як гармонічна підтримка голосу та темброворегістрові відлуння його мелодії; 3) середні голоси-втори до вокальної теми-мелодії, які в розвиваючому розділі (Agitato; Des-dur) перетворяться на токатний візерунок, що «згущує, ущільнює» фактурний простір та сприймається як хвиля емоційного збудження.

Мелос солоспіву «Я пережив свої бажання» в експозиції (простий період квадратної неповторної будови: $\mathrm{a}+\mathrm{b}$ ) запам'ятовується широтою дихання крупних фраз, експресією синтаксичного розгортання емоції-думки та іiї «згортанням». На тлі basso ostinato мелодична лінія солоспіву набуває благородної чеканки, стриманості та чоловічої гідності, навіть мужності. Семантика середнього розділу $\boldsymbol{B}$ гранично контрастує до попередньої сповіді душі. Пристрасть і відчай наповнюють декламаційну вокальну партію (на слова «живу в самотнім вічнім болі»!). Кульмінація на словах «і жду: чи прийде мій кінецьь» вражає магією «божественних довгих нот» $\left(\mathrm{g}^{2}\right.$ та fis ${ }^{2}$ дорівнюють цілому такту!), які важко подолати співакові як емоційно, так і технічно. Точна реприза врівноважує композицію поверненням в елегійний стан.

«Крук до круку» (в оригіналі «Ворон к воронулетит») - шотландська народна балада в перекладі О. Пушкіна. Вона близька до сімейних балад, про що свідчать тема та герої (убитий богатир і його дружина). Художня своєрідність балади полягає в тому, що діалог в ній - основний композиційний засіб організації сюжету. У композиції балади відсутні заспіви і кінцівки. Головна ознака балади - наявність сюжету, що наближає іiі до епічних жанрів (билини, казки). Тому вона може вважатися епічним жанром. Однак в баладах, на відміну від билин і казок, 
відсутні основні елементи сюжету (зав'язка, розвиток дії, кульмінація і розв'язка); наявний лише підсумок певних подій, які відбулися до початку розповіді. 3 розмови воронів слухач дізнається тільки про богатиря, якого вбито; але що сталося, ким убитий і чому, - невідомо.

Ворон к ворону летит, / Ворон ворону кричит:

«Ворон! Где б нам отобедать? / Как бы нам о том проведать?» Ворон ворону в ответ: / «Знаю, будет нам обед;

В чистом поле под ракитой / Богатырь лежит убитый».

Фінал балади відкритий: Кем убит и отчего, / Знает сокол лишь его, / Да кабылка вороная, / Да хозяйка молодая. Остання строфа підкреслює драматизм дії: богатир убитий, а дружина чекає на нього живого.

У баладі увага фіксується на одному-двох епізодах: немає ліричних відступів, докладного опису природи, зовнішності героїв. Крім того, у творі використовуються різні стилістичні засоби: епітети, символи, іносказання, порівняння, зменшувально-пестливі суфікси. Всі вони сприяють емоційній виразності балади, підсилюють трагізм іiі звучання. Душевні переживання героїв втілені за допомогою порівнянь, а також гіпербол і уособлень. Отже, балада поєднує в собі елементи епічної і ліричної поезії. Тому можна казати про спадкоємність між драматичним змістом балади та лірично-психологічним модусом авторського слова.

В. Косенко як глибокий психолог тонко передає природу вірша, слідуючи за кожним порухом поетичної фрази. Музичним аналогом поетичного смислообразу є семантика смерті. Автор використовує традиційну тричастинну форму $\mathrm{ABA}_{1}$, збагачуючи музичну драматургію твору повільним медитативним епізодом (В) і динамізованою репризою $\left(\mathrm{A}_{1}\right)$ суто інтонаційними засобами.

Експозицію складає простий період 3 двох речень повторної будови, а символом смерті стає зображення крука. Стилістику підкреслює маршеподібний темпоритм та характерний звукозображальний пунктирний малюнок у низхідному русі (наче крук б’є крилами, спускаючись зверху). Драматизація відбувається паралельно до колізії тексту (друге речення). Обраний малюнок інструментального супроводу посилює експресію у кульмінаційній точці: «в чистім полі жовте жито, там козаченька убито». На цих рядках образ жахливого чорного птаха посилений форшлагами і группето в акордовому викладі (зупинка на гармонії $\boldsymbol{D}$ - відкрита форма!). 
Середній розділ позначений зміною темпу (Andante), панує уповільнене сприйняття часопростору, медитативне «зависання» у філософських роздумах (розмір 6/4 встановлює половинну тривалість як часовимірну одиницю - замість четвертної). Тематизм дещо контрастує до попереднього (побудованого на звуках акордів D - T); хоча слух може віднайти похідні елементи, за мотивно-розробковим типом інтонування (псалмодія на словах «Хто й за щзо його убив») та тональним модулюванням. Драматургічний профіль розділу має вигляд сходження: від « $\mathrm{h}^{1} »$ до «h» малої октави (зупинка на субдомінантовій гармонії), що створює атмосферу психологічного занурення у передчуття трагедіiі. Наостанок вкажемо на колоритну секвенцію з перерваних зворотів: $\mathrm{D}_{2}$ до C-dur (що не звучить), A-dur; $\mathrm{D}_{2}$ (B-dur)-G-dur-fis-h. Велика фермата відмежовує середній розділ композиції від іiі репризного завершення (Allegro moderato).

Репризу відрізняє висхідна динамізація образно-емоційного стану, який перевищує за своїм трагічним відчуттям попередню смислову кульмінацію. Наче через розв'язку сюжету автор сповідує думку про цінність життя, однак висновок безжалісний: смерть косить все, навіть надію. У інструментальному супроводі на системній основі (кожна доля такту!) відтворені форшлаги з трьох хроматичних, варіантнозмінених оспівувань певного тону акордової вертикалі (T-D-T-D-S ). $^{2}$ У виконавському плані важливим $є$ уповільнення темпу наприкінці репризи, для підсилення враження від образу смерті. Отже, українська мело-інтонація та їі морфо-фонетика лише посилили трагічну сутність балади О. Пушкіна. Музична семантика твору В. Косенка позначена залежністю від загальноромантичного «словника»: мотиви оспівування, ходи по тризвукам домінантової, субдомінантової та тонічної гармоній; хроматичні (альтеровані) акорди. Слід вказати і на національні ознаки: висхідний малосекстовий (квінтовий) хід, який заповнюється поступовим протирухом; силабо-тонічне віршування; синтез мовної та пісенної інтонацій. Мелодія має колоподібну будову (розвиненість і широка інтерваліка сприяють звуковій емблематиці чорного птаха).

«Вечірня пісня» (Moderato) сприймається як семантичне переключення: від внутрішніх спогадів - до зовнішнього спостереження (пейзажний звукопис). Тональність B-dur традиційно пов'язана з символікою життєдайного світла: саме так відчув В. Косенко славетні пушкінські рядки («Редеет облаков летучая гряда,/ звезда печаль- 
ная, вечерняя звезда»). Мелодика «кружляє» навколо тонічного квартсекстакорду, із зупинками на сильних долях (тонкий штрих: «увядшие равниныл» звучить як відхилення в тональність III щаблю-d-moll), надаючи твердості оптимістичному погляду героя. Цікаве ладотональне зіставлення звучить наприкінці у репризі тричастинного середнього розділу (на слова «плещуть солодко гучні таврійські води»): b-moll-зб. VII ${ }_{7-}$ Es-dur-es-moll - $\mathrm{D}_{6 \mid 5}$-d-moll. Ця послідовність «зависає» (скінчується) на септакорді (великий з мажором), який є затриманням до тризвуку фрігійського ладу; разом з динамікою $p p$, довга фермата підкреслює завершення величної картини спогадів: «в дозвіллі мрійному текли за днями дні».

Фортепіанний супровід позначений віртуозним розмахом і блиском (звукозображання морських хвиль, яке чергується з хоральним співом радощів від спостереження дивної природи). Вкажемо на тонку деталь інтонування: початок репризи у вокальній партії (на слова «там юна дівчина») звучить у висхідному тетрахорді еолійського мінору (замість B-dur). Це характеризує мислення Косенка як поета, чуйного до психології вірша, і як меланхолійну людину-музиканта.

Загальна реприза позначена ноктюрновою фактурою, яка завершує концепцію вірша любовною семантикою, посиленою у коді висхідною мажорною поспівкою, що стверджує оптимізм психологічного настрою цього солоспіву. Після нього на слухача чекає разючий контраст з трагедійним фіналом циклу.

«Старовинна пісня» (Largo; f-moll) - стилізація павани. Складна двочастинна композиція $\mathrm{AB}-\mathrm{A}^{1} \mathrm{~B}^{1}$ (з розвиненою інструментальною постлюдією (16 тактів) починається з мелодії зачину (4+4), який звучить суворо, стримано, у хоральному складі: короткі поступові мотиви поволі розгойдуються, аж до натурального VII щаблю, і повертаються в тоніку. Ладогармонія містить тонічний органний пункт (що порушується лише в заключному кадансі), який додає пісенному образу архаїчного забарвлення (асоціація зі «Старовинним замком» 3 фортепіанного циклу М. Мусоргського «Малюнки з виставки»).

Другий розділ пісні (неквадратної будови 7+4) виконує функцію розвитку, про що свідчать декламаційні репліки («питання - відповідь») та ладотональна нестійкість (оспівування IV щаблю субдомінантової тональності b-moll). Завершує етап драматургічного розвитку пластична тема-мелодія у «шубертівській» тональності des-moll (за ра- 
хунок VI мінорного щаблю), що втілює романтичний відчай щодо помарнілої квітки (на слова «I хто побожною рукою нащсо сюди й коли поклав?»).

Повтор вокальної експозиції позначений варіантними преображеннями фортепіанного супроводу: якщо раніше він слугував второю для вокального співу, то тепер втора «обтяжена» акордовими гронами та додатковими підголосками, ще й важкими кроками басу. Ще більшими тематичними змінами (як наслідок переживання героєм фантазій щодо квітки) позначений розділ $B^{1}$. Ритмічне дроблення другої (слабкої) долі в супроводі додає широким мелодичним ходам секвенції вокальної партії внутрішньої напруги, підкреслюючи прихований пасакальний рух (від V щабля до тоніки, із задіянням хроматичних IV й III щаблів) - знак смерті! Особливо містично звучить повтор цього розділу з новим фактурним «одягом», в якому відгомін похоронного дзвону сприймається як післямова автора. Таке рішення «тихої» кульмінації $є$ більш динамічним, ніж гучні віртуозні пасажі. В цілому вкажемо на майстерне використання українським композитором європейських жанрових моделей пасакалії та павани, пов'язаних з образами смерті, душевними переживанням людини від втрати кохання, життя.

Висновок. Семантичний аналіз вокального твору В. Косенка op. 20 виявив стильові важелі впливу на композитора. 3 одного боку, поетична система О. Пушкіна належить до романтичної естетики, звідси В. Косенко як автор міжвидового перекладу мав визначитися із власною стильовою інтонацією. Ним задіяні звукозображальність у єдності з душевно-емотивним багатством, пісенні мело-формули (стрибок $3 \mathrm{~V}$ щабля на I; оспівування основного тону (II-VII-VI); висхідний стрибок на м. 6); жанрові знаки-індекси в інструментальній партії (ритмічна фігура «вісімка з пунктиром»), низхідний рух (заключні такти вокальної партіі); гармонічний мінор у заключному кадансі.

3 іншого боку, в умовах зміни вербального звучання віршів О. Пушкіна (українською мовою) народжується ментально інша інтонаційна мова; як наслідок - відбувається пересемантизація оригіналу, засвідчуючи «вихід» автора музики за межі загальноєвропейського впливу та встановлення національної «вокальної аури». Кожен 3 п’яти солоспівів увиразнює багатство мелосу, ладогармонії, фактурно-тембрового варіювання з урахуванням поетичного слова. Косенко ні разу не повторює інтонаційно-драматургічне рішення. 
Пошук власного прочитання звукообразної символіки і оригінального втілення у музичній драматургії пушкінської «картини світу» призвів до відкриття одного з найбільш ранніх зразків міжвидового художнього перекладу в новітній українській вокальній музиці, з яскраво індивідуальним жанрово-стилістичним синтезом європейського та російсько-українського «інтонаційного словника». У підсумку («цілісній адекватності», за А. Хуторською) переважає ментальний ліричний чинник і український образ світу. Сучасний слухач відкриває для себе стильову інтонацію вокальної музики В. Косенка як втрачену культуру «чуттєвих обертонів і магічних вібрацій» закоханої душі, яка надолужує «дефіцит лірики» в умовах руйнівної масової ерзац-культури глобалізованого світу.

\section{ЛІТЕРАТУРА}

1. Тюріна О. В. Косенко та Д. Шостакович у просторі пушкінської поезії (на прикладі романсів «Послання з Сибіру»). Науковий вiсник НМАУ імені П. І. Чайковського : зб. наук. ст. Вип. 66: Шостакович і XXI століття. До 100-річчя від дня народження. Київ, 2007. C. 286-291.

2. Хафізова Г. В. Стильові особливості перевтілення поезії Олександра Пушкіна у вокальних циклах: дис. ...канд. мистецтвознавства за спеціальністю 17.00 .03 - Музичне мистецтво. Київ, 2016. 199 с.

3. Хуторська А. Й. Композиторська інтерпретація поетичного тексту як художній переклад (на прикладі камерно-вокальної музики) : автореф. дис. ... канд. мистецтвознавства. Харків : ХДУМ ім. І. П. Котляревського, 2009. 17 с.

\section{REFERENCES}

1. Tiurina O. (2007). V. Kosenko ta D. Shostakovych u prostori pushkinskoi poezii (na prykladi romansiv «Poslannia z Sybiru») [V. Kosenko and D. Shostakovich in the space of the Pushkin Poetry (on the example of the Romances of "Messages from Sibir"]. Naukovyi visnyk NMAU imeni P. I. Chaikovskoho : zb. nauk. st. [The Science Herald of National Musical Academy of Ukraine named after P. I. Nchaikovsky : collection of research papers]. Iss. 66: Shostakovych i XXI stolittia. Do 100-richchia vid dnia narodzhennia [Shostakovych and XXI century. To the 100th anniversary of the birth]. Kyiv. 286-291 [in Ukrainian]. 
2. Khafizova H. V. (2016). Stylovi osoblyvosti perevtilennia poezii Oleksandra Pushkina u vokalnykh tsyklakh: dys. ...kand. mystetstvoznavstva za spetsialnistiu 17.00.03 - Muzychne mystetstvo [Stylistic features of the impersonation of Alexander Pushkin's poetry in vocal cycles : Ph. D. diss. ... in Art Studies, specialty 17.00.03 - Musical art]. Kyiv. 199 [in Ukrainian].

3. Khutorska A. Yo. (2009). Kompozytorska interpretatsiia poetychnoho tekstu yak khudozhnii pereklad (na prykladi kamerno-vokalnoi muzyky) : avtoref. dys. ... kand. mystetstvoznavstva [Composer' s interpretation of poetical text as art translation : Ph. D. diss. ... in Art Studies]. Kharkiv : Kharkiv State I. P. Kotliarevskiy University of Art. 17 [in Ukrainian].

Стаття надійшла до редакиії 01.09.2018 р.

УДК 792.028.4, DOI 10.34064/khnum1-5008

ORCID 0000-0003-1550-4239

Грінік Т. Л.

Харківський наиіональний університет мистецฺтв

імені І. П. Котляревського

Харківський державний академічний український

драматичний театр імені Т. Г. Шевченка

\section{ПРАКТИКА ІНТЕРПРЕТАЦІЇ ХУДОЖНЬОГО ТЕКСТУ. РОЗДІЛОВІ ЗНАКИ ЯК ЗАСІБ ВИРАЗНОСТІ ТА ЗАСВОСННЯ НАВИЧОК ЗВУКОВИДОБУВАННЯ}

АНОТАЦІЯ

Грінік Т. Л. Практика інтерпретації художнього тексту. Розділові знаки як засіб виразності та засвоєння навичок звуковидобування.

Статтю присвячено вдосконаленню роботи актора над оволодінням навичками сценічної мови. 3'єднання культурологічного (вихід у суміжні мистецькі сфери - літературну, музичну) та навчально-методичного підходів до аналізу процесу формування навичок сценічної мови дозволило побудувати у рамках дослідження 